form $\lambda$ A

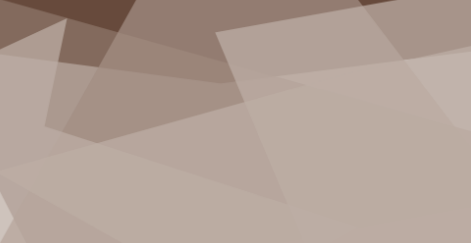

Eva Lutnæs

Professor (PhD)

Oslo Metropolitan University, Norway

evalu@oslomet.no

Vol I4, No 4 (202I)

\title{
Framing the concept design literacy for a general public ${ }^{1}$
}

\begin{abstract}
Educating the general public to be design literate can be a catalyst for both environmental protection and degradation, human aid and human-made disasters depending on how the scope of design is framed - and how 'design literacy' is defined. This paper explores how to cultivate design literacy that supports critical innovation and a transition towards more sustainable societies. The research approach is a literature review of key texts that promote and conceptualize design literacy as part of general education. Four narratives are identified as vital: a) 'Awareness through making', b) 'Empower for change and citizen participation', c) 'Address complexity of real-world problems', and d) 'Participate in design processes'. Moving towards more sustainable modes of consumption and production, a design literate general public provides a critical mass of users empowered to question how a new innovation supports the well-being of people and the planet and to voice their own ideas.
\end{abstract}

Keywords:

design literacy, literature review, critical innovation, general education.

\section{INNOVATIVE DESIGN OR CRITICAL INNOVATION?}

Progress depends upon the products of educated minds, stated UNESCO (1997) and launched education as humanity's best hope and most effective means towards sustainable development. Stephen Sterling (2001), however, claimed that: "most education daily reinforces unsustainable values and practices in society. We are educated by large to 'compete and consume' rather than to 'care and conserve'" ( $p$. 21). Educating the general public to be design literate can be a catalyst for both environmental protection and degradation, human aid and human-made disasters depending on how the 'design literacy' is defined and how the scope of design is framed. It makes a vast difference whether students are asked to design beautiful products to increase sales or to design useful and lasting products or services that improve quality of life and mitigate pollution. Vande Zande (2013) defined innovative design as a unique solution that creatively satisfies a problem. A valuable outcome of introducing design techniques of ideation to companies is how unique solutions might advance economic competitiveness and success 
in a globalized market (Canina, Coccioni, Anselmi, \& Palmieri, 2013; Martin, 2009). Judged meaningful in terms of business, innovative design, satisfy just one out of three mutually reinforcing pillars of sustainable development (United Nations, 2002) at the expense of social development and environmental protection.

Citizens of Western societies are facing what Stegall (2006) described as an: "extremely complex sociological dilemma, where the lifestyle that we have adopted is rapidly eroding our ability to survive" (p. 57). At the level of social equity, it would be favourable that all citizens of the world have the same economic vitality, but the capacity of the ecological system is already at its limits. Infinite economic growth, irrespective of its wider consequences, threatens not only social well-being and ecological sustainability, but also economic prosperity (Jackson, 2009; Meadows, Meadows, \& Randers, 1991). Mateus-Berr et al. (2013) argued that designers have played a considerable role in shaping today's consumerist culture by providing their skills and talents to create desire for new products. Design literacy will remain a driver of economic competiveness unless concerns for the environment and human well-being are made an explicit part of judging new ideas as meaningful or valuable. Mainstreamed as three equally important pillars, the global sustainable development agenda has focused too much on economic development, marginalizing both the social and environmental aspects (SANZ, 2009). We have not yet been ready for the task of large-scale changes in our unsustainable ways of living (Giddens, 2011; Intergovernmental panel on climate change, 2018). Critics called for a paradigm shift in which economic development is nested within social sustainability and environmental sustainability (Elmquist et al., 2014). Applying the paradigm shift as a baseline to design literacy requires critical scrutiny of how a newly proposed innovation supports a transition towards a more sustainable future. In the model below, critical innovation satisfies criteria of economic vitality, welfare of current and future generations, and safeguarding of the ecosystem:

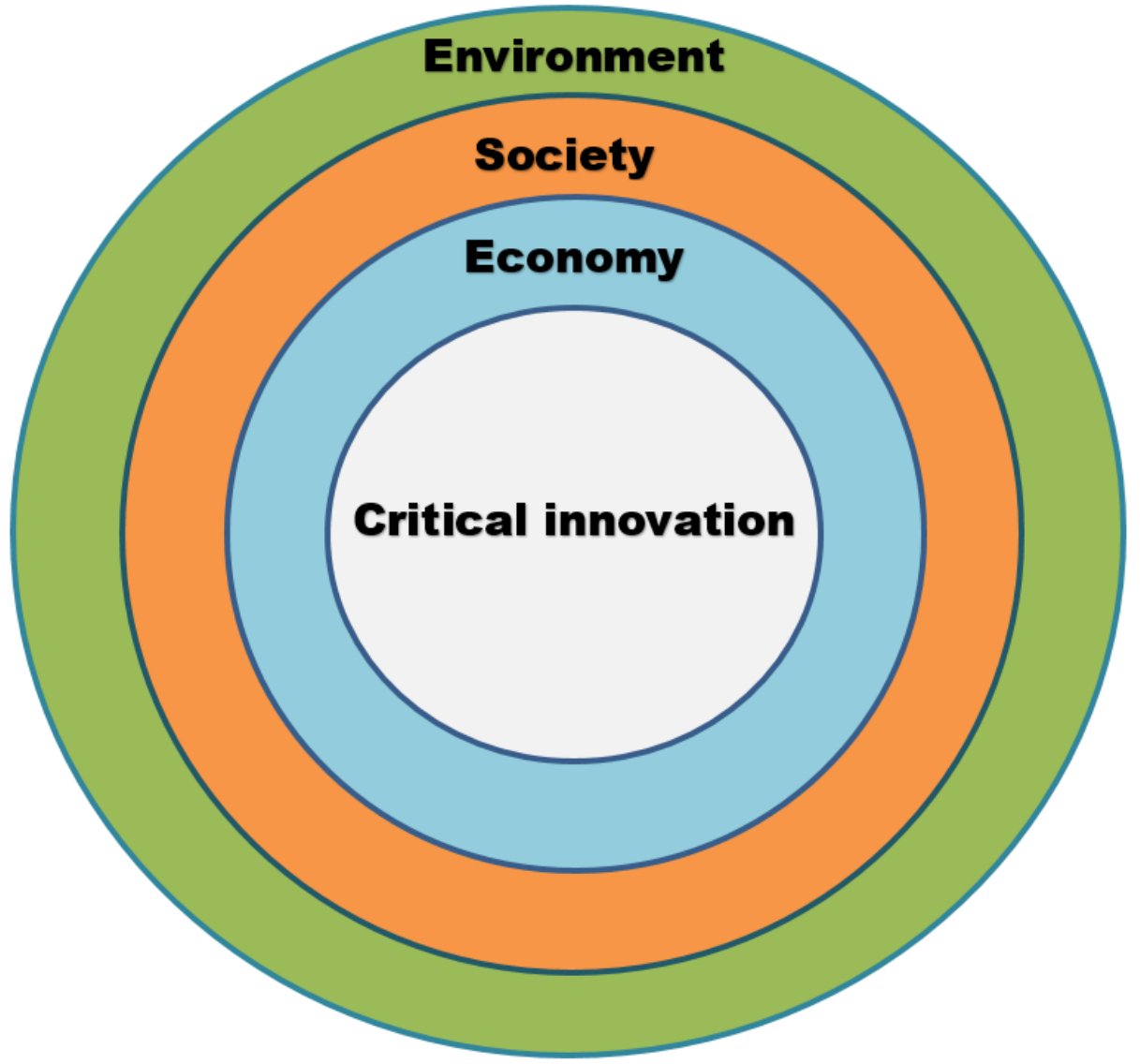

FIGURE 1. Critical innovation as nested within economic, social, and environmental sustainability. 
Relating the concept 'critical' to 'innovation' requires the facilitation of critical reflection as a baseline to any design process. Critical reflection addresses the fundamentals of practice, the why of action, and the reasons and consequences of what we do (Mezirow, 1990, p. 13). Critical innovation derives from asking basic ethical questions of how a new idea makes the world better and rejecting practices of overconsumption and destructive results of human creativity. Critical reflection called the foundations and imperatives of the system itself into question, assessed their morality, and considered alternatives (Brookfield, 2010, p. 219). The purpose of critical reflection is profound change in our attitudes and actions. Design and critical reflection share the same transformative agenda. In his seminal book, The Science of the Artificial, Herbert Simon (1969) described design as concerned with how things ought to be. The capacity to transcend the known is the expertise of design. According to Simon (1996): "Everyone designs who devises courses of action aimed at changing existing situations to preferred ones" (p. 111). Including design in any curricula fuels change by exploring and questioning existing knowledge and situations. In support of critical innovation, however, further effort is required. Critical innovation calls for everyone first to consider what situations to change, then the socio-ecological consequences of intended change, and who would benefit from a specific situation changing. Critical reflection is a key component to support a transition towards more sustainable modes of production, trade, and consumption. This paper explores how design literacy as a part of general education can support critical innovation and a possible move towards sustainable societies (Stegall, 2006). The research approach is a literature review of key texts that promote and conceptualize design literacy as part of general education. None of the texts synthesized the concept of design literacy into an explicit definition. By reviewing the key texts' storylines on how to cultivate design literacy, this paper aims to articulate a definition of design literacy for a general public in a context of critical innovation.

\section{STORYLINES AS A METHOD OF INQUIRY}

The literature review of key texts on design literacy for a general public is derived from Soini and Birkeland's (2014) approach when investigating the scientific discourse on the concept of 'cultural sustainability'. They used storylines as a semiotic tool to identify generative narratives used to give meaning to specific physical or social phenomena within a discourse (Hajer, 1995). The narratives in this study aim to give meaning to design literacy as a part of general education within the scientific discourse of design education. The discourse refers to ideas, concepts, and categorizations that are produced, reproduced, and transformed in the practice of writing academic papers. As a method of inquiry, storylines encompass complexity and provide a semiotic tool to voice different narratives in a specific discourse.

The first phase of the literature review identified papers that could inform the research question based upon the following criteria for selection: (1) incorporates 'design literacy' into the title, (2) focus on design literacy as part of general education, (3) enacts ethical responsibilities and critical reflection, and (4) written in English. The first criterion delimits the selection to papers in which authors have made design literacy one of the main concept. The second and third criteria ensure papers relevant to explore how to cultivate design literacy in general education and educate a general public empowered to support critical innovation (Figure 1). The fourth criterion enables transparency. As all the selected texts are written in an accessible language, the results of the study are open for inspection to other researchers, and the selected text can be reanalysed in future studies.

The search for relevant papers was completed in December 2018, using Skopus, Eric, Academic Search Premier, and Oria. This search identified eleven papers with 'design literacy' in the title. Three of the papers failed to satisfy criterion 2 as they discuss design literacy in a context of higher education (Formosa \& Kroeter, 2002; De Eyto, 2014; Poggenpohl, 2008). Four of the papers did not satisfy criterion 3, enact ethical responsibilities and critical reflection (Pacione, 2010; Jones, 2013; Lerner, 2018; Rahimi \& Kim, 2018). As criterion 3 is vital for design literacy to support critical innovation, I will explain how two of the papers failed to meet this criterion. In Lerner's (2018) paper 'Visual-Spatial Art and Design Literacy as a Prelude to Aesthetic Growth', design is framed as the process of giving form or expression to ideas. Lerner focus solely on the positive aspects of visual-spatial learning and involve no critical re- 
flection. Design literacy is limited to the ability to understand and make use of a canon of aesthetic form. Pacione (2010) named "the act of arranging how something looks" ( $p, 11)$ as a stereotype of design to stamp out in order to convince a majority of leaders in business and government to support design thinking in companies and as a vital part of general education. Pacione took on a broader understanding of design literacy than Lerner did as he described an iterative process of uncovering and satisfying unmet needs as core design capacities. Still, Pacione's (2010) paper, 'Evolution of the Mind: A Case for Design Literacy', falls short on criterion 3 as no attention was given to the wider social and environmental impacts of design - critical reflection on what unmet needs to satisfy or not by design. Pacione (2010) asked the question, 'What does it mean to be design literate?' (p. 9). In this paper, I ask the question again, but in a context of critical innovation.

Four texts met the criteria, and prior to a description of the second phase of the literature review, their focus and research approach are briefly introduced:

1. Nielsen and Brænne's (2013) 'Design Literacy for Longer Lasting Products' has a conceptual approach as they discussed how design literacy is located amongst other literacies and connected to material knowledge, ecological literacy, and citizenship.

2. Green's (2014) 'Transformational Design Literacies: Children as Active Place-Makers' draws upon an ethnographic study in an Australian primary school in which students aged 8-12 and their teachers designed and made a new garden, 'learning landscape', on the school grounds. The focus is on the potential role of design in a garden-based curriculum and how the children were positioned as participants.

3. Christensen, Hjorth, Iversen, \& Smith's (2019) 'Understanding Design Literacy in Middle-School Education: Assessing Students' Stances Towards Inquiry' presents a literature review on design thinking in children's education prior to a comparative study on how 449 students aged 11-15 took a designerly stance towards inquiry in a survey. The authors found no significant difference between how the control group and how the students who had received design education performed. The focus is on what it takes to educate for complex adaptive capabilities. The study is a follow-up on Christensen, Hjorth, \& Iversen (2016). Both papers satisfy all four criteria, and I chose the most recent one.

The second phase of the literature review started by reading the three texts, marking out descriptions on how to cultivate design literacy and for what reasons. Subsequently, a word search was used for a systematic approach by which key concepts in one paper were searched for in the other two.

Table 1, Preliminary analysis, key concepts across the three papers.

\begin{tabular}{llll}
\hline Key concept & Nielsen \& Brænne & Green & Christensen et al. \\
\hline Citizenship & $\mathrm{x}$ & $\mathrm{x}$ & $\mathrm{x}$ \\
\hline Democratic/democracy & $\mathrm{x}$ & $\mathrm{x}$ & $\mathrm{x}$ \\
\hline Materials/materiality & $\mathrm{x}$ & $\mathrm{x}$ & $\mathrm{x}$ \\
\hline Transformative/transformational & $\mathrm{x}$ & $\mathrm{x}$ & $\mathrm{x}$ \\
\hline Reflective inquiry/critical & $\mathrm{x}$ & $\mathrm{x}$ & $\mathrm{x}$ \\
\hline Dialogue & & $\mathrm{x}$ & $\mathrm{x}$ \\
\hline Open-ended process & & $\mathrm{X}$ & $\mathrm{x}$ \\
\hline Agency/agent & $\mathrm{x}$ & $\mathrm{x}$ & $\mathrm{x}$ \\
\hline Power/empower & $\mathrm{x}$ & $\mathrm{x}$ & $\mathrm{x}$ \\
\hline Awareness & $\mathrm{x}$ & $\mathrm{x}$ & \\
\hline Complex task/problem/dilemma & & & \\
\hline
\end{tabular}


The preliminary analysis (Table 1) was a tool to approach the texts from multiple angles and familiarize with shared concepts on design literacy across the papers. The identification of generative narratives, however, relied on the combination of concepts, as meaning is not produced by singular words. Valid narratives had to stand a test of being coherent to the meaning produced in each of the papers as well as descriptors across the three on how to cultivate design literacy in a context of critical innovations. A repetitive process of combining concepts to narratives, revisiting all three texts, moderating narratives and revisiting the texts, identified four shared narratives:

a) Awareness through making

b) Empower for change and citizen participation

c) Address complexity of real-world problems

d) Participate in design processes

Across the shared narratives, the authors voiced different objectives and ways of acquiring design literacy. The third phase of the literature review presents each of the narratives, and discuss nuances and different agendas in the three key texts.

\section{GENERATIVE NARRATIVES IN KEY TEXTS ON DESIGN LITERACY}

\section{a) Awareness through making}

A shared narrative among all three texts is the significance of placing materials in the hands of pupils. As makers, they transform materials to externalize ideas, and in the making, they connect both to the physical reality and to the conceptual in order to articulate meaning. Nielsen and Brænne (2013) stressed material knowledge as part of design literacy for consumers to opt for longer lasting products and sustainable choices in their everyday lives. Through the mode of making in physical materials, the demand of time and energy in production becomes a first-hand experience to pupils, as well as what it takes a product to become solid, functional, and interesting to use over time. The fusion of craftsmanship and design literacy is not self-propelled. In their making, the attention of pupils needs to be drawn to the plural context of materiality, a context described by Nielsen and Brænne (2013) as purpose, use, production, transport, ecology, and ethics.

In the narrative of Green (2014), embodied experiences in outdoor sessions teach pupils to work with, not in opposition to, the peculiarities of a garden site. Through months of rigorous mapping of trees, soil, wind, sun, and distance, the pupils accumulated knowledge of the site. Their ideas for the new garden evolved from knowing the material realities and a personal connection to the site. In the first part of the project, the materials were placed in the hands of the pupils for them to examine, and Green (2014) argued that the field trips were critical in empowering pupils to develop, shape, and modify their critical spatial thinking (p. 194). In the second part of the project, materials were placed in the hands of the pupils for them to change the garden site. Green emphasised how making models in clay and three-dimensional maps with a wide range of materials enabled the pupils to advance their ideas and voice their visions.

Christensen et al. (2019) presented design as a basic literacy akin to reading and writing. Skills for materializing ideas as externalizations is among their described learning outcomes for design literacy, alongside abilities of designerly inquiry, ideation, and navigating a design process. In their study, the access to materials and maker settings varied significantly from one school to the other. This was pinpointed as one of the reasons why the FabLab group of students did not perform significantly better than the control group of students in how they took a designerly stance towards inquiry. The authors thus indicated the importance of access to materials and proper studios for design literacy initiatives to succeed. In the article, the authors also entailed an interesting section on the potential pitfalls of the emerging new technologies that make the creation of digital products feasible in schools. As the introductory workshops for teachers usually are constrained to short sessions with predetermined outcomes, the teachers are more likely to opt for activities focused on technological literacy than design literacy. Activities enable pupils to repeat the design of others by the use of technology, but not to take 
part in the design process. The authors' warning draws attention to the importance of a wider repertoire amongst teachers developed by experiencing a long, complex, and open-ended process themselves prior to the cultivation of design literacy.

The three texts emphasise the importance of first-hand experiences with materials as part of educating a design literate general public. In Green's (2014) narrative, the students examined the physical reality of the garden site to connect to its potential, and in their making of models, they experienced how visualization in materials might voice and advance their ideas. The agenda in the narrative of Nielsen and Brænne (2013) was twofold: designing and making their own products (e.g. garments or spoons) prepared the pupils to judge quality and longevity in products as consumers and provided an arena to enhance pupils' awareness on how conflicts, inequity, and exploitation of nature embed everyday consumption. Christensen et al.'s (2019) narrative on making was to provide students with tools to externalize and share ideas. They emphasised the importance of open-ended briefs, as the making of copies rather would cultivate students' technological literacy than design literacy.

\section{b) Empower for change and citizen participation}

The idea of empowerment is a key to design literacy across the three texts, challenging a script of schooling with teachers as experts who hold pre-set answers for pupils to unveil. The educational ideas of Freire (1970) were present in all three texts on design literacy. Freire brought attention to what he framed as the banking concept of education by which students are receiving, filing, and storing narrations from the teachers. The banking concept offers few opportunities for students to analyse how political, cultural, and social contexts shape their lives. Freire's alternative is a practice of problemposing education. The teachers pose a problem that challenge humans' relations in the world and with the world, and they facilitate a dialogue of co-investigation with students to unveil oppression and situations as historical realities susceptible to transformation (Freire, 1970).

Christensen et al. (2019) promoted design literacy as part of education for citizenship and democracy, followed by an argument on how designerly ways of engaging with complex problems enable individuals to act as agents of change and creators of preferred futures. Seeking a single correct answer and relying on the same tried-and-tested method regardless of situation were described as opposites to the expertise of designers. The authors referred explicitly to Freire's criticism on the banking concept of education along with Biesta's (2008) concept of 'learnification' and Lin, Schwartz, \& Bramsford's (2007) difference between routine experts and adaptive experts. The authors did not elaborate further on Freire or propose design literacy explicitly as an alternative to the banking concept; adaptive expertise was their chosen concept to explain a designerly stance towards inquiry. Drawing upon a wide range of references, the authors framed a designerly stance towards inquiry as being open to new understandings, listening to the complexity by adapting a range of techniques, and gaining a holistic understanding of the existing situation (Christensen et al., 2019, p. 4). The authors found that the FabLab group of students who had received design education through middle-school maker settings failed to improve their designerly stance towards inquiry. Their study pinpointed the difficulties of implementing design literacy to general education and discussed how it challenged the more familiar scenario where the teacher 'has the correct solution to the problem at hand' (Christensen et al., 2019, p. 18).

Green did not quote Freire explicitly, but under the heading 'Agency', she described a shared feature of the countless facilitated discussions during the design of the new garden. They all positioned the pupils as the main stakeholders and required that they work with the emerging tensions and problems that arose during the design process. Green referred to an example of a discussion on how to incorporate a frog pond safely. The teacher's role was not to resolve the issue but to facilitate a space for dialogue among pupils 'that supported their "voice" and empowered them to successfully and safely incorporate a frog pond into the plan'. A key narrative in Green's text on design literacy is the importance of providing pupils with a sense of agency. The principal elaborates on how pupils' agency and decision-making is enhanced by inclusive and unhurried processes. Green connected agency to citizenship by quoting Mannion (2003) on how children are active local citizens of today who are capable of bringing a uniquely valuable perspective to civic discourse. Green positioned the pedagogy of design 
as a direct contrast to approaches that privilege teacher knowledge and position students as passive recipients, along with Freire's banking concept of education. According to Green, the pedagogy of design permits children to visualize the future and to see themselves as proactive participants with a significant role to play.

Nielsen and Brænne (2013) found the concept of design literacy as one bringing new life to the educational ideas of Freire (1970). The transformative agenda of design shares the ideas of Freire. The core of Freire's (1970) libertarian and humanist pedagogy was for people to discover themselves as permanent re-creators of the world: "To exist, humanly, is to name the world, to change it" (p. 88, original emphasis). In the text, knowledge of sustainable ways of producing and using material artefacts are key to design literacy for a general public, empowering them to refuse to buy unethical artefacts along with critical awareness of how groups are socialized as consumers and producers. Making design literacy a part of general educations enhances an alternative counterculture-a critical stance against shallow symbolic design-values and of being seduced through shopping to buy more than we need.

Empowerment of the individual pupil is a shared objective of design literacy, however, at different levels. The pupils in Green's narrative were empowered to voice their ideas and differing perspectives in the design of a garden. The pupils in Christensen et al.'s (2019) narrative were empowered to a designerly stance towards inquiry, to act as agents of change and create preferred futures. The pupils in Nielsen and Brænne's narrative were empowered to criticize and change the system in how they acted as consumers and producers. The last narrative is the one closest to Freire's more radical ideas on education as a means to challenge humans' relations in the world and with the world and to capacitate people to transform the sociocultural realities that shape their lives by their words and actions.

\section{c) Address complexity of real-world problems}

Design literacy is promoted as a tool to understand and deal with the complexity of real-world problems across the texts. In the narrative of Christensen et al. (2019), one argument of making design literacy a part of general education is how it facilitates awareness of the complex and wicked nature of problems. All real-world challenges are wicked, they claimed, and the pupils would be better equipped for their future if they developed a capacity to recognize problems as wicked (p. 4). With a reference to Lawson and Dorst (2009), taking on wicked problems is at the very core of design thinking and later elaborated as: "seeing the whole from multiple conflicting dialectical contradictions among stakeholders, including ethical, political, and even spiritual ones" (p. 16). In their study, the authors assessed how Danish middle-school pupils approached a wicked problem of demented elderly disappearing from nursing homes and how to create a secure environment for them without taking away their freedom. Only $5.69 \%$ of the FabLab group of students and $2.46 \%$ of the control group of students made a designerly stance towards inquiry by explicitly or implicitly recognized wicked aspects of the question posed. The vast majority approached the question with a stance of technical rationality, seeing the wicked problem as tame and focusing on answers that were readily at hand, e.g. implementing a GPS-device under the skin with no consideration of ethical dilemmas (Christensen et al. 2019).

Green's narrative has similarities to Christensen et al. (2019) in describing key features of design literacy as the ability to engage with an unknown outcome and connect to the complexity of the real world. In Green's study, the children were encouraged to undertake detailed mapping of the site for the new garden and 'to work with a degree of uncertainty and chaos alongside adults who support them to visualize the future and make it happen'. Quite contrary to Christensen et al. (2019), Green (2014) concluded with a successful implementation of design literacies in how children are recognized as practitioners who can undertake complex tasks, think critically, solve problems creatively, and apply design knowledge to new situations. Christensen et al.'s (2019) study drew upon a quantitative survey across 17 schools, while Green followed a long-term design project linked to a cornerstone in the school's charter, learning landscapes, and a pedagogical commitment to environmental studies for the past 20 years. Green's (2014) study supports Christensen et al.'s (2019) in their conclusion on how children might develop complex adaptive capabilities given more design education over a longer period.

Nielsen and Brænne's take on complexity was to emancipate the field of design from being 
associated with only form and colour, not on the complexity of the design task itself. They connected design literacy to Stegall's ecological literacy (2006) and the sociological dilemma of rapidly eroding our ability to survive through the lifestyles we have adopted. Vital to design literacy for a general public, they argued, is awareness of how choices as consumers impact the soundness of the ecological system, knowledge of materials, and the complex process of making and designing sustainable products. Drawing upon Stegall (2006), Nielsen and Brænne made the point that even the most sustainable product would not be sustainable unless every person used and recycled it in a responsible manner. The crucial game changer of overconsumption is the reflective user and responsible consumer who ask for sustainable design and buy only the goods they really need.

The capacity to embrace complexity and navigate solutions that contribute to a better future is a shared goal of the three papers in promoting design literacy for a general public. While Green (2014) and Christensen et al. (2019) focused on the complexity of the task given to the students and their inquiry into open-ended problem-solving, Nielsen and Brænne (2013) described the complexity of the knowledge involved to be a design literate person who opts for sustainable design and responsible consumption.

\section{d) Participate in design processes}

Narratives on the importance of personal experiences with design processes is present in all three papers. Green's (2014) object of study was a long-term design process in which students and teachers collaborated in the making of a garden, learning to landscape on the school grounds. She discussed how design literacies expand children's learning and deepen their connection to everyday places. Green's descriptions of the design process were rich and manifold, summed up as two main narratives: the physical and the collaborative. The physical process focuses on how the children connect to the site by rigorous mapping and first-hand observations, visualize their ideas through models and maps, and transfer ideas to a three-dimensional reality by building and gardening. The collaborative process is parallel to the physical, focusing on how the teachers position the students to voice their meaning, debate ideas, and agree on final designs as proactive and empowered learners.

Christensen et al. (2019) developed a design process model for the FabLab group students and their teachers. The researchers made the model sequential to simplify the complexity of the design process, consisting of six phases: design brief, field study, ideation, fabrication, argumentation, and reflection. In a later survey, they asked the FabLab group of students how familiar they were with each of the six phases, and more than half of the students rated themselves as knowledgeable. When the students were challenged to address a wicked problem, however, they were not able to adapt their knowledge derived from working with the design process model and take a designerly stance towards inquiry. The authors concluded that the students gained some routine expertise on the design process during their engagement with the project, but not the adaptive capabilities of designers.

Nielsen and Brænne (2013) had no description of phases in a design process or what procedural skills the students should acquire to be design literate, but they promoted students' understanding of the complex process of making or designing as vital. Core to design literacy, they argued, is awareness of how design processes have an impact on our surroundings and the physical aspects of material quality regarding what is lasting and functional. Their proposed route to these competencies for students included making with physical materials and a 'reflection in action' approach. Although not stated explicitly by the authors, this implies that students should actively engage in a design process that combines skills of physical visualization with inquiry and critical reflection about the impacts on people and the ecological system.

In Green's (2014) narrative, student participation in the design process offered expanded learning opportunities to the garden-based curriculum and supported them as active place-makers. The design process offered a method to facilitate learning and empower students for ideation. Christensen et al. (2019) made the understanding of designerly inquiry and ability to navigate a design process as the main learning objectives, while Nielsen and Brænne (2013) focused on student awareness of the social and ecological impacts of design processes. 


\section{WHAT DOES IT MEAN TO BE DESIGN LITERATE?}

Pacione's (2010) answer to the question of what is meant by being design literate, as opposed to being a design professional, is basic skills in inquiry, evaluation, ideation, sketching, and prototyping. Pacione described phases of a design process, the fourth narrative identified in the three key texts: $d$ ) 'Participate in design processes'. Repeating Pacione's question in a context of critical innovation adds three additional narratives: a) 'Awareness through making', b) 'Empower for change and citizen participation', and c) 'Address complexity of real-world problems'.

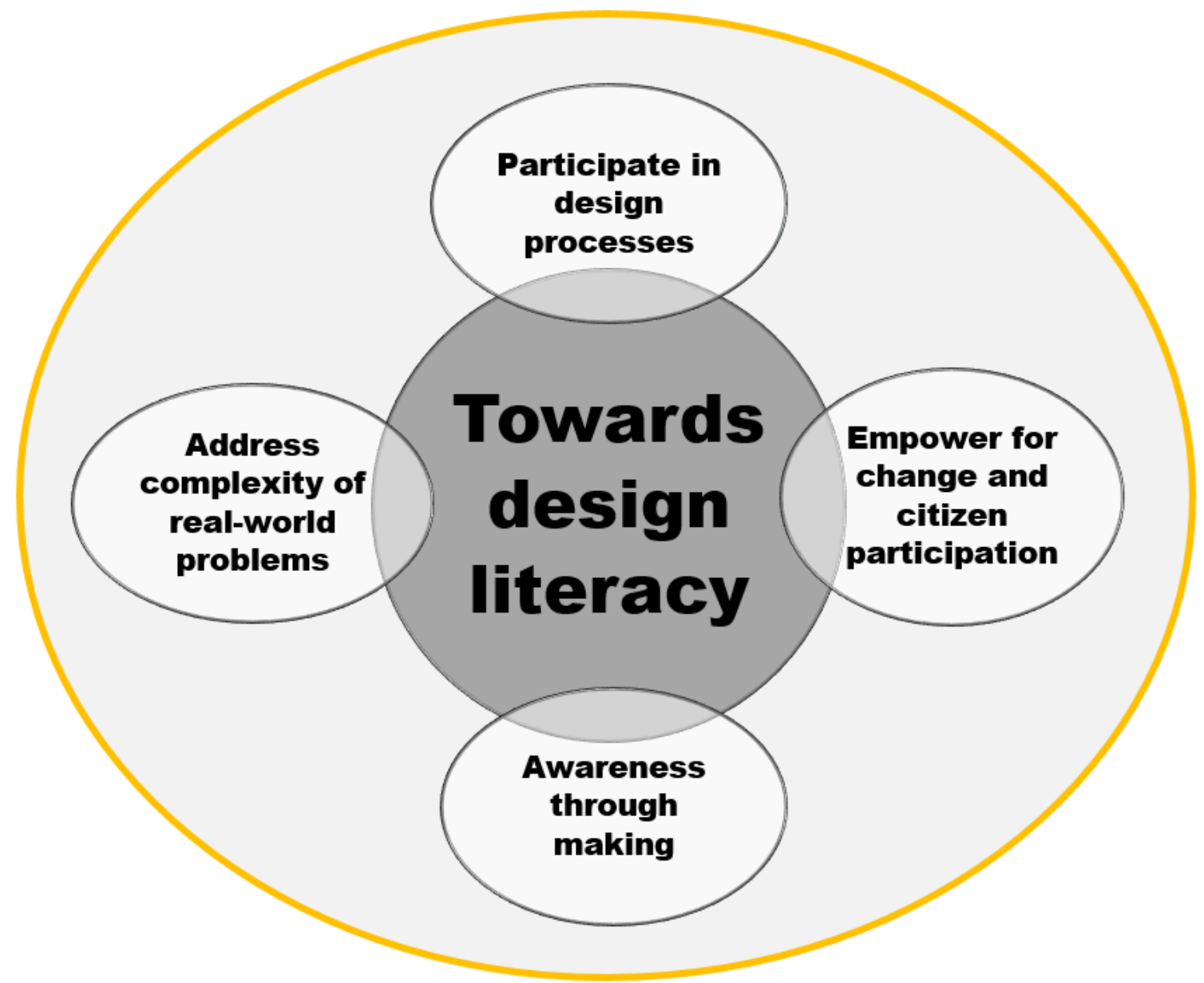

FIGURE 2. Sketch of a conceptual framework on how to cultivate design literacy in support of critical innovation.

Reading and revisiting the three key texts identified four shared narratives on how to cultivate design literacy amongst a general public. a) 'Awareness through making' draws upon the significance voiced by the authors of placing materials in the hands of the pupils. As makers, they transform materials to externalize and advance ideas, and in the making, they connect both to the physical reality and to the conceptual in order to articulate meaning. Awareness indicates understanding of the socio-environmental impact of human-made artefacts, and what it takes for products to be solid, functional and interesting to use over time. b) 'Empower for change and citizen participation' is a shared narrative on the importance of providing students with a sense of agency and tools to question, rethink, and transform the world around them. Everyone has a significant role to play towards more sustainable ways of living or further destruction, and the authors promoted design literacy as a game changer towards more responsible citizen participation. c) 'Address complexity of real-world problems' is framed as a key feature of design literacy, and accordingly, students are challenged to map and navigate conflicting interests and dilemmas embedded in design practices and solutions. d) 'Participate in design 
processes' is the fourth narrative towards design literacy, endorsed by the authors as enabling students to adopt the designer's tools for innovation and understand how designers think. Figure 2 displays a sketch based on generative narratives on how to cultivate design literacy, derived from a literature review of three different texts. So far, the scientific discourse on design literacy in context of critical innovation is in an early stage of development; the number of articles that could satisfy the four criteria for selection are few. This preliminary sketch would evolve as design literacy is addressed and challenged by further academic writing.

\section{Defining design literacy in a context of critical innovation}

The three key texts reviewed to identify generative narratives on design literacy as part of general education were published between 2013-2018. The idea of introducing design thinking to general education, however, is not a recent one, see e.g. Archer (1973/2005) or Cross (1982). Looking back at the initial arguments on why design awareness represents an important area of educational development, we can see some striking similarities to more recent scientific discourse. Design is a basic way of knowing along with humanities and sciences to serve us in our daily lives and in preparation for social roles (Cross, 1982). Design education was not introduced by Archer (1973/2005) as a means to shape consumerable items, but to meet "urgent need for the survival as well as the happiness of mankind" (p. 46). The role of design education is empowering the individual for participation in daily life and society. To participate, one needs to know the codes in order to act in line with expected practices. Understanding design as a form of literacy expands the purpose of design education to empower for criticism and transformation. The concept of literacy adds resilience by empowering individuals to challenge established regimes of knowledge and structures of society (Boehnert, 2015; Illeris, 2012). Kolko (2018) combined participation and transformation: "To be literate is to have a voice in society, and to see the things that are happening, build on them, change them, and reject them" (section 11). For a professional designer, transformation as the ability to change an object or service for the better is key, but for the general public, transformation might prove more powerful as rejection of unsustainable design. One aim of identifying generative narratives on how to cultivate design literacy in key texts was to attempt a definition of design literacy in a context of critical innovation. Drawing on the four generative narratives (Figure 2) and ideas of participation and transformation embedded in the concept of literacy, I suggest the following definition:

Being design literate in a context of critical innovation means to be aware of both positive and negative impacts of design on people and the planet, approaching real-world problems as complex, voicing change through design processes, and judging the viability of any design ideas in terms of how they support a transition towards more sustainable ways of living.

\section{Coda}

Addressing the complex problem of overcoming a world made unsustainable (Fry, 2009), basic ethical questions of how a new innovation supports the well-being of people and the planet prove just as important to integrate into general education as into the education of professional designers. As Craft (2005) stated: "Promoting children's creativity in the context of wider ethical dimensions of our existence is not an optional extra" (p. 149). In a context of critical innovation, a core part of the teacher's role would be to draw the students' attention to how any design idea would satisfy real-world problems responsibly and towards a better tomorrow. Students need to recognize their capacity to transform unsustainable design practices as informed consumers and to challenge established regimes of policy, fundamentally rethinking definitions of human needs and desires (United Nations Environment Program, 2011). Only a few of a student cohort will become professional designers, but all of them are users of professional designers' innovations in their everyday living and as future employees. In support of critical innovation, the value of cultivating design literacy amongst a general public is empowering a critical mass of users who recognize their capacity to transform unsustainable patterns of living by the products and services they voice and opt for as consumers, democratic participants, and employees. 


\section{REFERENCES}

Archer, B. (2005). The Need for Design Education. In B. Archer, K. Baynes \& P. Roberts (Eds.), A Framework for Design and Design Education. A reader containing papers from the 1970s and 80s (pp. 16-21). Data and Loughborough University. (Original work published 1973)

Biesta, G. J. J. (2008). Good education in an age of measurement: On the need to reconnect with the question of purpose in education. Educational Assessment, Evaluation and Accountability (Formerly: Journal of Personnel Evaluation in Education), 21(1), 33-46. https://doi.org/10.1007/s11092-008-9064-9

Boehnert, J. (2015). Ecological literacy in design education: A theoretical introduction. FormAkademisk, 8(1), 111. https://doi.org/10.7577/formakademisk.1405

Brookfield, S. (2010). Critical reflection as an adult learning process. In N. P. Lyons (Ed.), Handbook of Reflection and Reflective Inquiry: Mapping a Way of Knowing for Professional Reflective Inquiry (pp. 215-236). Springer. https://doi.org/10.1007/978-0-387-85744-2_11

Canina, M., Coccioni, E., Anselmi, L., \& Palmieri, S. (2013). Designing a creativity training plan for companies. In J. B. Reitan, P. Lloyd, E. Bohemia, L. M. Nielsen, I. Digranes, \& E. Lutnæs (Eds.), Proceedings of the 2nd International Conference for Design Education Researchers: Design Learning for Tomorrow - Design Education from Kindergarten to PhD, (vol. 4, pp. 1907-1923). ABM-media. https://hdl.handle.net/10642/8893

Christensen, K. S., Hjorth, M., Iversen, O. S., \& Blikstein, P. (2016). Towards a formal assessment of design literacy: Analyzing K-12 students' stance towards inquiry. Design Studies, 46, 125-151. https://doi.org/10.1016/j.destud.2016.05.002

Christensen, K. S., Hjorth, M., Iversen, O. S., \& Smith., R. C. (2019). Understanding design literacy in middle-school education: Assessing students' stances towards inquiry. International Journal of Technology and Design Education, 29, 633-654. https://doi.org/10.1007/s10798-018-9459-y

Craft, A. (2005). Creativity in schools: Tensions and dilemmas. Routledge. https://doi.org/10.4324/9780203357965

Cross, N. (1982). Designerly ways of knowing. Design Studies, 3(4), 221-227. https://doi.org/10.1016/0142$694 \times(82) 90040-0$

De Eyto, A. (2014). 'Growing oak threes'-education for sustainable design: Building a sustainable design literacy in undergraduate and professional designers. In K. D. Thomas \& H. E. Muga (Eds.), Handbook of Research on Pedagogical Innovations for Sustainable Development (pp. 584-604). IGI Global. https://doi.org/10.4018/978-1-4666-5856-1.ch030

Elmquist, T., Cornell, S., Öhman, M. C., Daw, T., Moberg, F., Norström, A., Persson, Å., Peterson, G., Rockström, J., Schultz, M., Török, E. H. (2014). Global sustainability and human prosperity: Contribution to the post2015 agenda and the development of sustainable development goals. Nordisk Ministerråd. https://doi.org/10.6027/TN2014-527

Formosa, K., \& Kroeter, S. (2002). Toward design literacy in American management: A strategy for MBA programs. Design management journal, 13(3), 46-52. https://doi.org/10.1111/j.1948-7169.2002.tb00318.x

Freire, P. (1970). Pedagogy of the oppressed. Seabury Press.

Fry. T. (2009). Design futuring: Sustainability, ethics and new practice. UNSW Press. https://doi.org/10.5040/9781350036079

Giddens, A. (2011). The politics of climate change (2nd ed., rev. and updated ed.). Polity.

Green, M. (2014). Transformational design literacies: Children as active place-makers. Children's Geographies, 12(2), 189-204. https://doi.org/10.1080/14733285.2013.812305

Hajer, M. (1995). The politics of environmental discourse. Oxford University Press.

Illeris, H. (2012). Nordic contemporary art education and the environment: Construction an epistemological platform for art education for sustainable development (AESD). InFormation. Nordic Journal of Art and Research, 1(2), 77-93. https://doi.org/10.7577/information.v1i2.221 
Intergovernmental panel on climate change. (2018). Global Warming of $1.5^{\circ} \mathrm{C}$. Summary for Policy Makers. https://www.ipcc.ch/site/assets/uploads/sites/2/2018/07/SR15_SPM_High_Res.pdf

Jackson, T. (2009). Prosperity without growth: Economics for a finite planet. Earthscan. https://doi.org/10.4324/9781849774338

Jones, V. (2013). STEM design literacy strategy: Capture natural curiosity. Children's technology \& Engineering, 18(1), 28-31.

Kim, B., \& Bastani, R. (2018). Game design literacy as a problem-solving disposition. Proceedings of International Conference of the Learning Sciences, ICLS. 1743-1744

Kolko, J. (2018, 20 Aug.). We are illiterate [Blog]. The Modernist Studio. http://www.themoderniststudio.com/2018/08/20/we-are-illiterate/

Lawson, B., \& Dorst, K. (2009). Design expertise. Taylor \& Francis.

Lerner, F. (2018). Visual-spatial art and design literacy as a prelude to aesthetic growth. The International Journal of Art and Design Education, 37(1), 65-73. https://doi.org/10.1111/jade.12110

Lin, X., Schwartz, D. L., \& Bransford, J. (2007). Intercultural adaptive expertise: Explicit and implicit lessons from Dr. Hatano. Human Development, 50(1), 65-72. https://doi.org/10.1159/000097686

Mannion, G. (2003). Children's participation in school grounds developments: Creating a place for education that promotes social inclusion. International Journal of Inclusive Education, 7(2), 1447-1540. https://doi.org/10.1080/13603110304784

Martin, R. L. (2009). The design of business: Why design thinking is the next competitive advantage. Harvard Business Press. https://doi.org/10.1093/jdh/epp037

Mateus-Berr, R., Boukhari, N., Burger, F., Finckenstein, A., Gesell, T., Gomez, M. ... Verocai, J. (2013). Social design. In J. B. Reitan, P. Lloyd, E. Bohemia, L.M. Nielsen, I. Digranes \& E. Lutnæs (Eds.), Design Learning for Tomorrow. Design Education from Kindergarten to PhD. Proceedings from the 2nd International Conference for Design Education Researchers (vol. 1, pp. 431-441). ABM-media. https://hdl.handle.net/10642/8890

Meadows, D. H., Meadows, D. L., \& Randers, J. (1991). Beyond the limits: Confronting global collapse, envisioning a sustainable future. Earthscan Publications.

Mezirow, J. (1990). Fostering critical reflection in adulthood: A guide to transformative and emancipatory learning. Jossey-Bass.

Nielsen, L. M., \& Brænne, K. (2013). Design literacy for longer-lasting products. Studies in Material Thinking, 9, 19. https://materialthinking.org/sites/default/files/papers/SMT_V9_07_KarenBraenne_LivNielsen_0.pdf

Pacione, C. (2010). Evolution of the mind: A case for design literacy. Interactions, 17(2), 6-11. https://doi.org/10.1145/1699775.1699777

Poggenpohl, S. (2008). Design literacy, discourse and communities of practice. Visible language, 42(3), 213-235.

Rahimi, F. B., Kim, B. (2018). The role of interest-driven participatory game design: considering design literacy within a technology classroom. International Journal of Technology and Design Education, 29(2), 387404. https://doi.org/10.1007/s10798-018-9451-6

SANZ. (2009). Strong sustainability for New Zealand. Principles and scenarios. Nakedize.

Simon, H. A. (1996). The sciences of the artificial. Third edition. M.I.T. (Original work published 1969)

Soini, K., \& Birkeland, I. (2014). Exploring the scientific discourse on cultural sustainability. Geoforum, 51, 213223. https://doi.org/10.1016/j.geoforum.2013.12.001

Stegall, N. (2006). Designing for Sustainability: A Philosophy for Ecologically Intentional Design. Design Issues, 22(2), 56-63. https://doi.org/10.1162/desi.2006.22.2.56

Sterling, S. (2001). Sustainable education: Re-visioning learning and change (Vol. no. 6). Green Books for the Schumacher Society. 
United Nations Educational, Scientific and Cultural Organization (UNESCO). (1997, November). A transdisciplinary vision for concerted action.

http://www.unesco.org/education/tlsf/mods/theme_a/popups/mod01t05s01.html

United Nations. (2002). The Johannesburg declaration on sustainable development, 4 September 2002. http://www.un-documents.net/jburgdec.htm

United Nations Environment Program. (2011). Visions for change: Recommendations for effective policies on sustainable lifestyles. http://unep.fr/shared/publications/pdf/DTIx1321xPAVisionsForChange\%20report.pdf

Vande Zande, R. (2013). K-12 design education, creativity, and the corporate world. In J. B. Reitan, P. Lloyd, E. Bohemia, L. M. Nielsen, I. Digranes, \& E. Lutnæs (Eds.), Proceedings of the 2nd International Conference for Design Education Researchers: Design Learning for Tomorrow - Design Education from Kindergarten to PhD, (vol. 4, pp. 2185-2195). ABM-media. https://hdl.handle.net/10642/8893

\footnotetext{
${ }^{1}$ First published as Lutnæs, E. (2019). Framing the concept design literacy for a general public. Conference Proceedings of the Academy for Design Innovation Management, 2(1). The article is republished with permission.
} 